\title{
Diatom analysis of the Euro-Arctic urban lakes sediments
}

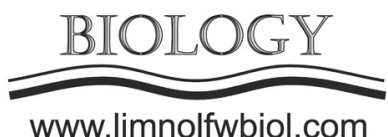

\author{
Denisov D.B.*, Kosova A.L., Slukovskii Z.I., Vokueva S.I. \\ Institute of the North Industrial Ecology Problems (INEP)-Subdivision of the Federal Research Center, Kola Science Center of the Russian \\ Academy of Sciences, Apatity, Russia
}

\begin{abstract}
Diatom records from Euro-Arctic urban lakes sediments have been carried out. It was reconstructed significant changes in the diatom taxa composition as a response on anthropogenic pollution and transformation of catchments area. Diatom assemblages from diverse urban aquatic ecosystems reflect the current Arctic climate warming, industrial pollution and eutrophication. Diatom records from surface sediment $(0-1 \mathrm{~cm})$ can be as an integral environmental assessment for the urban lakes ecosystems and water quality tool. Historical anthropogenic mineralization and alkalization of Lake Semenovskoe (Murmansk, Russia) have been reconstructed.
\end{abstract}

Keywords: diatoms, urban lakes, Arctic, paleolimnological reconstruction

\section{Introduction}

Socio-economic development of the Russian Arctic is provided by a powerful mining complex. The industrial activities aggravated the environmental problems, including rational use and quality of urban fresh water. Further exploitation of natural water resources and industrial development is impossible without knowledge about long-term trends in the ecosystems transformation, which is a scientific basis for nature management adapting to the environmental challenges and negative consequences minimizing. The studies of the pre- industrial historical dynamic of environment become actual at Modern Arctic warming (Ylikörkkö et al., 2015). Diatoms sediments records are a sensitive and reliable indicator of environmental changes. Therefore, the interpretation and disclosure of the paleolimnological data of the Euro-Arctic inland water bodies is needed in diatom analysis for long-term changes occurred in the last centuries.

\section{Material and methods}

The material for the research was the diatom assemblages (DA) from the lake sediments (LS) of the various urban freshwater bodies of Northern Fennoscandia, sampled in 2013-2018, including the largest lake of the Murmansk region - Imandra and several small lakes located in the catchment of the Paz River (Patsojoki). We used surface LS (0-1 cm layers) as well as sediment cores for the analysis. DA from Lake Semenovskoe $\left(\mathrm{N} 68,991007^{\circ} \mathrm{E} 33,088033^{\circ}\right)$ is located in the City of Murmansk have been analyzed too. Sampling, processing and analysis of samples were carried out according to standard generally accepted methods, and the scheme described earlier (Denisov, Genkal, 2018). It were used to assess of the quality of environment and the state of water bodies, indicators of taxonomic diversity, ecological structure and quantitative characteristics. The chemical composition of the waters and LS were carried out in the analytical laboratory of the INEP KSC RAS (Sandimirov et al, 2019).

\section{Results and discussion}

Diatoms - indicators of water quality and the ecosystem state, which can be used for regional monitoring were highlighted for the Lake Imandra by the LS surface layers analysis. Relative abundance of planktonic diatoms Stephanodiscus alpinus Hust. and $S$. minutulus (Kütz.) Cleve \& Möll. can be reliable indicators of anthropogenic transformations of Lake Imandra, associated primarily with the supply of nutrients, as well as other types of pollution. The maximum abundance of these taxa were in the water area under apatite and metallurgical industries pollution, where wastewater content the high amount of nutrients. The average phosphate content in the water of these areas is more than $3.0 \mu \mathrm{gP} / \mathrm{L}$, and the phosphorus concentration in LS is more than $9000 \mu \mathrm{g} / \mathrm{g}$.

On the contrary, relative abundance of Cyclotella radiosa (Grun.) Lemm. and Pantocsekiella comensis (Grun.) Kiss \& Ács, indicates the absence of intense 
water pollution. These species mainly are abundant in areas remoted from sources of pollution, where the average phosphate content in water is less than 1.0 $\mu \mathrm{gP} / \mathrm{L}$, and the phosphorus concentration in LS is less than $3000 \mu \mathrm{g} / \mathrm{g}$. The abundance of these species can be recommended for the water quality assessment of large Arctic urban lakes and phosphorus load regulation.

The effectiveness of this approach was confirmed by to compare of the DA from modern (surface) LS with the "pre-industrial" of ten different lakes of the catchment of the Paz River. The lakes are under different degree of pollution via the Pechenganikel (Norilsk Nikel) plant emissions. It was shown that the modern diatom species richness is depended from the intensity of pollution by the priority regional pollutants- heavy metals $\mathrm{Cu}, \mathrm{Ni}, \mathrm{Cd}$, as well as the level of pollution.

The DA record of the LS core ( $44 \mathrm{~cm}$ long) from Lake Semenovskoe have been analyzed. Significant rearrangements in the taxonomic composition and structure from the pre-industrial layers to the surface were revealed. According to diatoms autecology, the increase in the mineralization at the present stage has been shown. Anthropogenic alkalization of the lake is occurred. There was a change in $\mathrm{pH}$ - tolerance diatoms groups while the relative abundance of acidophiles decreased from $73 \%$ to $14 \%$, and the alkaliphiles and alkalibionts increased from $4 \%$ to $77 \%$. The diatominfer reconstructed $\mathrm{pH}$ values indicate a change from acidic conditions (6.6) to alkaline (7.5). The result of the impact to toxic pollution on Lake Semenovskoe is the high amount of diatoms with the aberrant frustules. These diatom were occurred in the upper $17-18 \mathrm{~cm}$ of the LS core, and was corresponded with the beginning of intense pollution.

\section{Conclusions}

The most dramatic changes in the Arctic urban lakes ecosystems were in the modern period (20- $2^{1 \text { th }}$ ), which is explained by strengthening of the anthropogenic pollution and degradation on the catchments. Diatoms habitat in Lake Imandra are mainly depended from the type and an intensity of anthropogenic impact. DA from the surface LS can be successfully used for an integrated water quality assessment. The ecosystem of urban Lake Semonovskoe have been transformed by heavy pollution, which led to alkalization of waters and increase in mineralization, in compare with pre-industrial period. It is necessary to develop a comprehensive study of the urban LS in the Arctic, the processes of sedimentogenesis and the taxonomic diversity of diatom complexes for detail paleoecological reconstructions, as a scientific basis for predicting future changes in the Arctic freshwater systems.

\section{Acknowledgments}

The investigations were funded by research project 0226-2019-0045 (data interpretation) and partially supported by the RFBR grants 18-05-60125 Arctic and 18-05-60142 Arctic (diatom analysis); sediments geochemical analysis was funded as part of the RSF grant 19-77-10007.

\section{References}

Denisov D.B., Genkal S.I. 2018. Centric diatom of lake Imandra (Kola Peninsula, Russia). International Journal on Algae 20(1): 27-36. https://doi.org/10.15407/alg28.01.057

Sandimirov S.S., Kudryavceva L.P., Dauvalter V.A. et al. 2019. Methods of ecological research of Arctic water bodies. Murmansk: publishing house of MSTU. (in Russian)

Ylikörkkö J., Christensen G.N., Kashulin N. et al. 2015. Environmental Challenges in the Joint Border Area, Reports 41; Centre for Economic Development, Transport and the Environment for Lapland; Juvenes Print: Kokkola, Finland. 